\title{
Economic Globalization, Income Inequality and Economic Growth in Nigeria: A Static Data Analysis (1986-2010)
}

\author{
Oluwatosin O. Ogunyomi ${ }^{1}$, Olusegun Richard Daisi ${ }^{2}$, Rasaq Adebola Oluwashikemi ${ }^{3}$
}

${ }^{1,3}$ External System, Lagos State University, NIGERIA

${ }^{2}$ Department of General Studies, Lagos State Polytechnic, NIGERIA

\begin{abstract}
This study examines the impact of economic globalization on income inequality and economic growth in Nigeria from 1986 to 2010. The study methodology was mainly Static Linear Econometric Model. Two models were used to test the two dependent variables simultaneously. The findings revealed that economic globalization had caused a widening income inequality as well as reduced economic growth of Nigerian economy due to much emphasis on financial globalization and other macroeconomic imbalances rather than trade globalization. It is therefore recommended that for Nigeria economy to exploit the gains of economic globalization just like the Asian Tigers, the Government should demonstrate good governance at all tiers of government through protectionist domestic policy, fiscal efficiency, political stability, adequate infrastructural provisions and encourages entrepreneurship development in Non-oil sectors to drastically reduce income equality between the unskilled and skilled labours.
\end{abstract}

Keywords: Economic Globalization, Financial Globalization, Trade Globalization, Economic Growth and Income Inequality

\section{INTRODUCTION}

Globalization is defined as a comprehensive process of economic integration which enhances international mobility of national resources and increases interdependency of national economics (OCED 2005, P. 11). Therefore, globalization is a multidimensional phenomenon, which covers all aspect of social, economic, political and cultural sphere.

However, the most concerns for economists are economic globalization and its consequences on national economies within and between countries of the world.According to Bhagwati (2004, P. 3) defined economic globalization as integration of national economies into the international economy through trade, Foreign Direct Investment (corporations and multinationals); Short term capital flows; international flows of workers and flows of technology.

Historically, the advent of economic globalization to many countries of the world was a result of the debt crisis suffered by many countries in 1980s. This was in the form of high inflation rate and worsening balance of payment positions. The aftermath of this crisis led the International Monetary Fund (IMF) and World Bank (WB), under the guise of "Washington Consensus" to facilitate a guided economic restructuring in the number of 
countries. Therefore, the Less Developed Countries (LDC) were asked to open up their economics and integrate with the world economic through adopting Structural Adjustment Programs (SAP); Post - SAP through economic liberalization and now emerged globalization in the Less Developed Countries.

Theoretically, the proponents of economic globalization argued that integration into the global economy promotes economic growth, which in turn helps to solve problems of poverty, inequality, lack of democracy and pollution and a considerable reduction in poverty. Therefore, these aforementioned benefits aroused the aspiration and expectation of Nigeria to embrace the economic policy of Globalization, through Structural Adjustment Programme in 1986 under the administration of Ibrahim Babangida.

In recent time, Globalization had been widely perceived by both Pro-globalist and antiglobalist as a dual sided phenomenon, which had been beneficial to many developed countries but has not helped matters in most developing countries like Nigeria. Therefore, a quantum of research had proven theoretically and empirically that globalization had a mixed outcome. The anti-globalist argued that globalization adversely affects the poor and particularly poor countries creating an increase income inequalities within and between the countries of the world while the pro-globalists claimed that it has led to higher growth employment generation and poverty reduction (Roud and Whalley, 2002; Abid and Anila, 2005, Atif et al, 2012 and Bussmann, SoysaandOneal, 2005) in Asia Tigers like China, Japan, Korea provides an example of a positive effect of globalization on growth. The spectacular growth of the countries of East Asia raised per capital / income by eightfold and raised hundreds of millions out of poverty. However, in some regions Americans Countries, SAP has led to depressing economic prospects. Similarly, most African countries that had embraced economic globalization had resulted to structural economic divergence; i.ewidening income inequality, collapse of Infant Industries because of the dependency International theory and less of economic convergence, informed by technology transfer, increased market size and relative employment generation.

Therefore, the mixed effects and unambiguous literature debates of the impact of economic globalization on income inequality and dismal record on economic development has brought to fore as well as the threats to national economic development within developing countries and between developing and developed countries on the other hand Greenway et al (2002); Kemal et al (2002), Almas (2003). Furthermore, they claimed that globalization affect growth in different countries in different way due to difference in government policies, population growth rate and the different institutional factors across countries.

Based on the inconclusive evidence among scholars and policymakers on the various degree of the costs and benefits of economic globalization. This paper therefore tends to empirically examine the effect of economic globalization on income inequality and economic growth in Nigeria between 1986 and 2012. Other objectives includeascertaining the causes of income Inequality in Nigeria and recommendations for making the positive gains of globalization totranslate to economic development of Nigeria.The rest of the paper is divided into four sections: Section II deals with the review of Literature and Theoretical Framework. Section III discusses methodology and sources of data. Section IV presents results and discussion while section $\mathrm{V}$ contains the conclusion and recommendations. 


\section{LITERATURE REVIEW}

\section{Review of Theoretical Literature}

Economic globalization on the other hand refers to the integration of the domestic economies with the world economy and the inevitable consequential increase in the economic interdependence of the countries through trade, financial and investment flows, free factor movements and exchange of technology and information. Thus, openness and markets constitute the platform of globalization while trade, finance and investment and entrepreneur are the heart (Obadan, 2003).

The concept of inequality and income inequality on the other hand connote the absence of sameness, evenness or equality while the latter in development economics theory examines the extent of income distribution in a particular place or country or system. According to Todaro and Smith (2003), income distribution could be measured from the standpoint of the personal or size distribution of income and the functional or distributive factor share distribution of income. The personal or size distribution of income measures the total incomes received by individual persons or households. That is, the level of income received by the richest quintile, decile or percentile of a population compared with the level of incomes received by the poorest quintile, decile or percentile of the population respectively. While the functional or factor distribution of income measures the share of total national output or income that each factor of production received (Todaro and Smith, 2003).In summary, out of the two explored methods of measures income inequality, economist often uses the personal income distribution.

Theoretically, there are various methods of measuring income inequality, namely the quintile, decile and percentiles approaches; another methods employed is the Kuznets ratio, which uses the ratio of the total income of the richest 20 percent to the total income with respect to the poorest 40 percent of the population. Another recent method of measuring personal distribution of Income is the Lorenz curve, which shows the cumulative frequency distribution of a given valuable, i.e income compared with the uniform distribution that represents equality. The most widely used single measure of income inequality is apparently the Gini coefficient. It can be obtained by calculating the ratio of the area between the diagonal and the Lorenz curve to the total area of the semi square in which the curve lies. Jhingan (2002) defines economic growth "as the process whereby the real per capita income for a country increases over a long period of time. " it is often measured by a percentage change in gross (or real) per capita national product (GNP). Several factors have been identified as causes of economic growth. These includes advancement in technology, international trade or degree of openness of the economy or trade liberalization, human capital and education, foreign capital inflow and investment, sound macroeconomic (fiscal, monetary, exchange rate and incomes) policies and institutions; good governance, physical capital formation etc.

From the above, it is clear that globalization, income equality and economic growth are related theoretically. Globalization is often associated with less restrictive trade regimes resulting in more openness of the economy with concomitant increase in volume of trade, which generates higher income among the people. Therefore, the theory of openness argued that the higher the level of openness, the better economic performance of the host country, which affects economic growth within and between the countries of the globe.

Economists have more thoroughly considered the effect of trade on the distribution of incomes within countries. According to neo-classical theory, free trade should decrease inequality in developing countries because they have a comparative advantage in unskilled 
labour. Trade increases the income of the factors of production used intensively by exporters. Cooper (2001) concludes recent empirical results are consistent with the view. Borsu and Glejser (1992) and Reuvemy and Li (2003) reported that the trade to GDP ratio is associated with more equitable income distribution in both the core and the periphery. International trade theory implies that increased trade and foreign investment should make income distribution more equal in poor countries and less equal in rich countries.

However, the prominent theory of income inequality was advanced by Kuznets (1955) when he relates income inequality within countries to their average income. Kuznet noted that the beginning of income inequality is traceable to the era of industrial Revolution, whereby people moved from the agricultural occupation characterized with uniform low incomes into cities, and earned higher wages in industry. He concluded that economic development might similarly affect the distribution of income, and a number of studies support Kuznets' theory (Weede and Tie fenbach, 1981; Muller 1988; Higgins and Williamson 1999; Barror 2000; Bhalla 2002; Reuvemy and Li 2003); but others have been contradictory in the time series analyses (Chan 1989; Anand and Kanbur 1993).

According to Lindert and Williamson (2001); O'Rourke (2001), and Aghion and Williamson (1998) in their study of the link between globalization and inequality state that increased world income inequality has been driven by between country rather than within - country inequality. Theory suggests that globalization will have very different implications for within - country income inequality, depending on the dimension of globalization involved, on the country concerned, and on the distribution of endowments. The world economy has become more globally integrated that can be interpreted as globalization has raised inequality between nations. The direction of impacts on the within country inequality depends on participating country's changes in their policy to exploit it. The source of income inequality in a globalized world with vast regions with inferior education and chaotic institutions could be poor government and non-democracy but not globalization.

In summary, the theoretical research on the link between globalization growth and income inequality was discussed from the standpoint of three growth theory. The neo-classical growth theory predicts convergence (increasing equality) because of increase mobility of capital through international trade. However, the endogenous growth theory predicts less convergence or divergence (increasing income inequality) because of increasing return to technological innovation in developed countries and absence of fundamental macroeconomic structure to exploit the gains of globalization in less developed countries. Finally, the dependency growth theory predicts that divergence (increasing income inequality) is more likely because of differentials in benefits from the economic integration and trade and locked production structure in Less Developed Countries (LDCS). Therefore, it was established theoretically that Globalization has increased income inequality between country while the within - country income inequality or distribution cannot be fully linked to globalization, but rather due to by the countries inferior education, chaotic institutions, poor governments and non - democratic domestic redistributive politics.

\section{Review of Empirical Literature}

Globalization and its linkage with economic growth and income inequality between countries and within countries over the past decade had degenerated to a lot of controversies among scholars and policymakers. Various studies had proven that globalization increases growth as well as widening income inequality between countries and even within - countries of the world, whereas other numerous studies found that globalization had reduce income inequality within - countries as well as equal growth 
between countries. In this study for value judgement between the pro-globalist literature and anti-globalist literature, the research extensively analyses the various literature conclusion, in order to draw an inference on the controversy issue.

Neutel and Heshmati (2006) examined relationships between globalization, inequality and poverty. Their results from cross-national regression analysis show that there is a significant relationship between globalization and income inequality. Agenor (2002) examined the extent to which globalization affects the poor in low-and middle income countries. He began with a description of various channels through which trade openness and financial integration may have an adverse effect on poverty. Agenor presented crosscountry regressions that relate measures of real and financial integration to inequality. He used not only individual indicators of trade and financial openness but also a "globalization index" based on principal components analysis, and tested for both linear and nonlinear effects. His results suggested that there is inverted U-shape relationship between globalization and inequality. At low levels, globalization appears to hurt the poor; but beyond a certain threshold, it seems to reduce poverty-possibly because it brings with it renewed impetus for reform. Figini and Gorg (1999) analyzed the effects or multinational companies wage inequality in the host country. Their empirical results for the Irish manufacturing sector between 1979 and 1995 suggested that there is an inverted $\mathrm{U}$ shape in wage inequality. They found that the presence of MNCs, which increases the demand for skilled labour, leading to rising wage inequality between skilled and unskilled workers. Over time, indigenous firms learns the new technology by imitating MNCs, and previously unskilled workers become skilled through working with the new technology. This, subsequently, leads to a decrease in wage inequality.

Feenstra and Hanson (1997) examined the increase in the relative wages of skilled workers in Mexico during the 1980s. they argued that rising wage inequality in Mexico is linked to capital inflows from abroad. The effect of these capital inflows, which correspond to an increase in outsourcing by multinationals from the United States and other northern countries, is to shift production in Mexico towards relatively skill-intensive goods thereby increasing the relative demand for skilled labor. They found that growth in Foreign Direct Investment (FDI), as a progress in globalization is positively correlated with the relative demand for skilled labor. In the regions where FDI has been most concentrated, growth in FDI can account for over 50 percent of the increase in the skilled labour share of total wages that occurred during the late 1980s and 1990s, reducing the inequality rate.

Milanovic (2003) presented another attempts to discern the effects of globalization by using data from household budget surveys and looking at the impact of openness and foreign direct investment on relative income shares of low and high deciles. He found some evidence that at very low average income levels, it is the rich who benefit from openness. As income level rises to those of countries such as Chile, Colombia, or Czech Republic, for example, the situation changes, and it is the relative income of the poor and the middle class that rises compared with the rich. It seems that openness makes income distribution worse before making it better, or differently in that the effect of openness on a country's income distribution depends on the country's initial income level. Furthermore, Adams (2007) examined the impact of globalization on income inequality for a cross section of sixty two developing countries over a period of seventeen years. The results of the study indicate that globalization explains only 15 percent of the variance in income inequality. This findings suggest that globalization has both costs and benefits and that the opportunity for economic gains can be realized within an environment that supports and promotes sound and credible government institutions, education and technological development. 
Wan et al. (2007) discussed China's globalization process and estimated an income generating function, incorporating trade and FDI variables. They found that globalization constitutes a positive and substantial share of regional inequality and the share rises over time. Also economic reform inequality, and finally the relative contributions of education, location, urbanization and dependency ratio to regional inequality have been declining. Cornia (2003) reviewed changes in global, between - country and within - country inequality over 1980 - 2000 against the background of the shifts that occurred in this area during the globalization of 1870 - 1914. He found that recent changes in global and between - country inequality are not marked and depend in part on the conventions adopted for their measurement. In contrast, within - country inequality appears to have risen clearly in two thirds of the seventy three countries analyzed mainly because of the policy drive towards domestic deregulation and external liberalization. Meschi and Vivarelli (2009) used a dynamic specification to estimate the impact of trade on within country income inequality in a sample of sixty five developing countries (DCs) over the 1980 - 1999 periods. Their results suggested that trade with high income countries worsen income distribution. Sato and Fukushige (2009) analyzed the determinants of theGini coefficient for income and expenditure in South Korea between 1975 and 1995. In both cases, they did not find support for the Kuznets inverted-U hypothesis. From an economic globalization viewpoint, the opening of goods markets reduces income inequality in both short run and long run. On the other hand, the opening of capital markets may increases income inequality in both period.

Borjas and Ramey (1994) use cointegration techniques to investigate causal effects between various explanatory variables and income inequality for the United States. It is concluded that the only explanatory variable that follows a significant long term trend to income inequality is the durable goods trade deficit as a percentage of GDP. Using trade as a proxy to globalization, the study suggests a positive relationship between inequality and globalization. A particular strength of this paper is the rigor of the econometric time series analysis. Robust statistical inferences tests are presented that demonstrate the validity of the models employed. However, the primary limitation of this analysis is that the source data relates only to the USA. It is therefore not appropriate to apply conclusions obtained from this analysis to other economies, particularly those of developing nations.

Edwards (1997) investigates the relationship between trade policy and income distribution by regressing Ginicoefficient over six different indicators of trade openness. The paper concludes that there is no evidence to suggest that trade liberalization, or increased globalization, has any significant impact on income inequality (Edwards 1997, p209).The discussion regarding measurement issues of the trade indicators is a relative strength of this paper. But using more than one measures of trade liberalization, the analysis shows that some indicators of increased trade improve income distribution, others have the opposite effect. Therefore, the analysis concludes absence of any clear link between increased trade and income inequality. A limitation of the analysis, however, is that the final Ordinary Least Squares regression model is not statistically significant with $\mathrm{R} 2=0.28$ (Edwards 1997, p. 209).

Marjit, Beladi and Chakrabarti (2004) provide a theoretical analysis of the possible impact of trade on income inequality. In particular, the analysis focuses on the gap between skilled and unskilled labour in a small developing economy. The analysis suggests a strong decline in the relative income of unskilled labour following an improvement in the terms of trade.This paper particularly highlights that an overwhelming majority of the research on the impact of globalization on income inequality has been carried out on data from the North which can be regarded as a definite strength of this paper. However, as the 
discussion is predominantly theoretical, a limitation of this paper is the lack of econometric modeling to support the conclusions presented.

Bergh and Nilsson (2011) examine the link between globalization and within country income inequality, after adding several control variables and controlling for potential endogeneity using GMM. They included that reforms towards economic freedom seem to increase inequality mainly in the North; whereas social globalization is more important in the South. It is also found that monetary, legal and political globalizations do not tend to increase inequality. This paper has the distinct advantage of making a distinction between different forms of globalization. In addition, this paper presents robust econometric analysis with a large sample of panel data (80 countries, 1970 - 2005). In particular, the $\mathrm{KOF}$ index is used as a measure of Globalization, and the Economic Freedom Index of the Fraser Institute is used to measure within country income inequality.

Zhou et al. (2011) investigate the impact of globalization on income inequality distribution in 60 developed, transitional and developing countries in 2000. It wasrevealedthat globalization can either alleviate or worsen the income inequality,

In summary, most of the empirical literature in the past nine yearsevaluated in this study shown that the debate on the impact of modes of globalization, either economic globalization, Political globalization or otherwise is still controversial and inconclusive. But there was a large consensus that the impact of globalization betweencountries resulted to higher income growth in developed countries and widening income inequality between less developed countries while a divergence views were concluded on the effect of globalization within countries, in respect to growth, poverty and income inequality. The objective of this paper is to provide strong empirical evidence on this divergent issue, with evidence from the Nigerian Economy.

\section{Methodology}

\section{Model Specification}

The model I used in this study wasadapted from the works of Agene (2003) and Mahler (2001) who looked at the relationship between income inequality and the main modes/set of globalization, such as economic globalization, political globalization and social globalization between or within country or region across countries.

The model II also took a lead from the Mundel Fleming model of open macroeconomic, which advocated that the more open an economy, the higher the rate of economic growth. This openness model is expressed in a function as:

Where

$$
Y=f(t / y, r, m g, f / y, i n, d p s)
$$

$$
\begin{aligned}
& \mathrm{Y}=\text { Growth rate of GDP } \\
& \mathrm{t} / \mathrm{y}=\text { Index of Trade Openers, i.e total trade to GDP. } \\
& \mathrm{r}=\text { real exchange rate } \\
& \mathrm{mg}=\text { real growth of money supply } \\
& \mathrm{f} / \mathrm{y}=\text { Ratio of fiscal deficit / surplus to GDP } \\
& \text { In = Inflation. } \\
& \text { Dps = Degree of Political Stability }
\end{aligned}
$$

Based on the empirical and theoretical framework models examined. This study derived two models specification to examine the impact of Economic Globalization on economic growth and income inequality in Nigeria, as represented in equation (1 and 2) below:

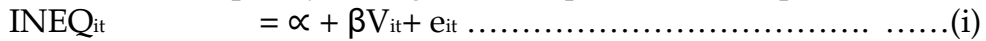

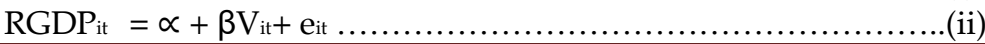


Where INEQ ${ }_{i t}$ is the dependent variable, representing the income inequality measured by GINI coefficient. The variable $V_{\text {itis }}$ a non-constant vector of $i$ regression for $i=1,2, \ldots . t$. Thus, for our empirical estimation, the two models of this study were expressed in the subsequent section.

\section{Model I}

$\mathrm{INEQ}=\mathrm{f}(\mathrm{TGLOB} ; \mathrm{FGLOB}, \mathrm{DPS}, \mathrm{FB}, \mathrm{CESS})$ eqn (iii)

The OLS linear regression equation based in the above functional relation was written as: $\mathrm{INEQ}=\beta_{0}+\beta_{1}$ FGLOB $+\beta_{2}$ FGLOB $+\beta_{3}$ DPS $+\beta_{4}$ FB $+\beta_{5}$ CESS $+U$ eqn(iv)

Aprion expectations of signs of parameters are stated below:

$\beta_{0}<0 ; \beta_{1}<0 ; \beta_{2}<0 ; \beta_{3}<0 ; \beta_{4}<0, \beta_{5}<0$

$\beta_{0}<0$ is supported by the Dualist Economy Theory that advocate that if all the workers had been the rural area and engaged a agricultural then income of workers would had been relatively equal.

Both $\beta_{1}$ and $\beta_{2}$ are expected theoretically to be $<$ because of the assumption of neoclassical growth theory who postulated that globalization would guaranteed income equality (convergence) within and between country of the globe.

While other parameters of $\beta_{3}, \beta_{4}$ and $\beta_{5}$ all were expected to be less than $(<0)$ which assumes reduction in income inequality within the country.

The definitions of the variables used in the model I above were expressed as:

INEQ = Income Inequality is proxied as Gini coefficient of Nigeria, derived from the World Bank Development Indicators.

$\mathrm{TGLOB}=\quad$ Trade Globalization, Otherwise known as Trade Liberalization, proxied as sum of total exports and Imports as a ratio of RGDP.

FGLOB $=\quad$ Financial Globalization proxied on the ratio of FDI to RGDP.

DPS $=\quad$ Degree of Political stability, which measures the number of years of democracy in the country. The presence of democracy is coded as " 1 " while non - presence of democracy is coded as " 0 ".

$\mathrm{FB}=$ Fiscal Balance proxied as index of Good Governance.

CESS $=\quad$ Capital Expenditure on Economic Services, representing the infrastructural development, by summing capital expenditure on Power, Telecommunication, Transportation and other Productive Capacity or utilities.

$\mathrm{U}_{\mathrm{t}}=\quad$ Error term

\section{Model II}

$$
Y=f\left(t / y, \text { fin } / y, R, m^{s}, f / y, \text { Infl, DPS }\right)
$$

The OLS linear regression equation based in the above functional relation was expressed as:

GRGDP $=\beta_{0}+\beta_{1}\left(\frac{T}{Y}\right)+\beta_{2}\left(\frac{\text { Fin }}{y}\right)+\beta_{3} R+\beta_{4} M^{\mathrm{s}}+B_{5}\left(\frac{F}{Y}\right)+\beta_{6} \operatorname{Infl}+\beta_{7} D P S+e_{t}$

Where

GRGDP $=\quad$ Growth Rate of RGDP

$\left(\frac{T}{Y}\right)=$

Index of Trade Globalization (openness) proxied as ratio of total trade (Export $=$ import) to RGDP.

$\frac{\text { Fin }}{\mathrm{y}}=\quad$ Index of Financial Globalization Proxied as ratio of FDI to RGDP

$\mathrm{R}=\quad$ Exchange Rate in nominal value

$\mathrm{M}_{\mathrm{s}}=\quad$ Money supply in nominal value. 
$\frac{\mathrm{F}}{\mathrm{Y}}=\quad$ Ratio of fiscal deficit/surplus (fiscal balance) to RGDP

Infl $=\quad$ Inflation Rate

DPS $=\quad$ Degree of Political Stability.

Aprioriexpectations of signs of parameters were stated below:

$B_{0}>0 ; B_{1}>0 ; \beta_{2}>0 ; \beta_{3}>0 ; \beta_{4}>0 ; \beta_{5}>0$ and $\beta_{6}<0$.

\section{Hypothesis Testing}

The specified regression model of eqn (4) and (6) demonstrated the empirical testing of the underlisted hypotheses of the study:

Hypothesis I: $\quad$ Economic Globalization does not cause income inequality within Nigeria.

Hypothesis II: Economic Globalization does not lead to economic growth of Nigeria.

\section{Estimation Techniques and Data Sources}

Equation 4 and 6 were estimated by the Ordinary Least Square (OLS) method through E-views software 7.0. The annual time series data for this study are sourced from the World Bank Development Indicators (2013), the Central Bank of Nigeria (CBN) Statistical Bulletin (2010) and National Bureau of Statistics (NBS) Publications (2010) for the period range of 1986 - 2010.

\section{Presentation And Discussion of Results}

This section present the results of the OLS for the model as specified in equation 4 and 6 . The results are presented in table 4.1 and 4.2 as estimated through 7.1 E-view computer packages.

\section{Table I: OLS (Model I)}

Dependent Variable: I

Method: Least Squares

Date: 06/06/13 Time: 16:03

Sample: 19862010

Included observations: 25

\begin{tabular}{lllll}
\hline Variable & Coefficient & Std. Error & t-Statistic & Prob. \\
\hline \hline C & 38.88248 & 0.891664 & 43.60665 & 0.0000 \\
TGLOB & -0.469687 & 0.135643 & -3.462668 & 0.0026 \\
FGLOB & 22.37124 & 4.091203 & 5.468132 & 0.0000 \\
DPS & 0.665468 & 1.430602 & 0.465167 & 0.6471 \\
FB & $-2.11 \mathrm{E}-06$ & $2.23 \mathrm{E}-06$ & -0.945786 & 0.3561 \\
CEES & $2.11 \mathrm{E}-06$ & 6.47E-06 & 0.326599 & 0.7475 \\
\hline \hline R-squared & 0.699357 & Mean dependent var & 43.48800 \\
Adjusted R-squared & 0.620241 & S.D. dependent var & 3.313900 \\
S.E. of regression & 2.042178 & Akaike info criterion & 4.471474 \\
Sum squared resid & 79.23936 & Schwarz criterion & 4.764005 \\
Log likelihood & -49.89343 & Hannan-Quinn criter. & 4.552610 \\
F-statistic & 8.839581 & Durbin-Watson stat & 1.900255 \\
Prob(F-statistic) & 0.000181 & & & \\
\hline \hline
\end{tabular}

Source: Authors' Computation

From the above table, the result of the regression analyses shows that the correlation coefficient and coefficient of determination of this model are $83.6 \%$ and $69.9 \%$ respectively. This implies 
that according to a priori expectation and conformity with empirical evidence that there was a strong relationship between income inequality and economic globalization within countries. The result shows a degree of strong correlation coefficient (R) of $83.6 \%$ between income inequality and presence of economic globalization in Nigeria between 1986 and 2010.

Furthermore, the result of coefficient of determination (R2) shows that the explanatory variables explained a total variation of $69.9 \%$ (percent) in the dependent variable (Income Inequality). This implies that the widening income inequality was as a result of the presence of included explanatory variable such as economic globalization, poor infrastructural facilities and political instability or weak democracy in the country, Nigeria between 1986 and 2010. Therefore, the result shows a good fit of the model.

On a priori ground, only trade globalization and fiscal balance have their expected negative sign which indicates that there is negative relationship between them and income inequality in Nigeria. This implies that the presence of trade liberalization/globalization had contributed towards reducing income inequality between the rich and the poor in Nigeria between 1986 and 2010. Also, the $t$ - statistics of -3.46 shows that the result is statistically reliable and sufficient for reducing income inequality in Nigeria at 5\% (percent) level of significance.In addition, the coefficient value of fiscal balance of -2.11 also revealed that the government policies taken within the research time frame had been helpful in reducing income inequality in Nigeria through the financial sectors reforms such on Banks Reform, Insurance Reform, Privatization and Commercialization Policy, all and more had helped to reduce the income inequality in Nigeria between 1986 and 2010. However, the $t$ - statistics value of -0.945 shows that the result is not statistically reliable and sufficient to achieve income equality in the Nigeria economy at $5 \%$ level of significance, except there is total implementation of these policies rather than the surface scratch approach, due to corruption among the political leaders.

The other included regressors in this model disagree with the apriori expectation of negative signs but all shown a positive signs which implies that financial globalization, degree of political stability (DPS) and capital expenditure on economic services (CEES), all have a positive relationship with income inequality in Nigeria between 1986 and 2010 . This implies that presence of foreign direct investment (FDI), portfolio investment and others financial globalization as well as weak democracy and lack of adequate infrastructural facilities like good road networks; efficient transportation and communication services and others, all contributed adversely to a raising income inequality between the rich and the poor in Nigeria. It was revealed that out of the three explanatory variables that contributed to income inequality in Nigeria, only financial globalization was highly significant and reliable to have caused a widening Income inequality within the Nigerian Economy between 1986 and 2010.

Finally, the F - statistics value of 8.84 with a corresponding low probability value of (0.000181) indicates that the overall model is statistically significant and reliable for both short - run and long - run prediction at $1 \%$ and $5 \%$ level of significance. Also, the DurbinWaston (DW) which is 1.900 shows that there is no serial correlation in the model.

In summary, the empirical results of this model concluded that economic globalization doescause income inequality within Nigeria between 1986 and 2010. It was further established that financial globalization, in terms of FDI have had a very strong association with increased income inequality while trade globalization, i.e Exports and Imports (trade liberalization) had only have a little/small significant association with reduced income inequality in Nigeria between 1986 and 2010. This estimation of this model was in support with Florence et al (2008) that uses panel regressionsbetween 1981 - 2003 within 20 
developed and 31 developing countries and found that trade and financial globalization appeared to have opposite effects on income inequality. They revealed that trade globalization leads to reduce income inequality while financial globalization increases income inequality, all at $5 \%$ level of significance.

Table II: OLS (Model II)

Dependent Variable: GRGDP

Method: Least Squares

Date: 06/06/13 Time: 16:57

Sample: 19862010

Included observations: 25

\begin{tabular}{lllll}
\hline \hline Variable & Coefficient & Std. Error & t-Statistic & Prob. \\
\hline \hline C & 0.041590 & 0.029150 & 1.426777 & 0.1718 \\
TGLOB & -0.001787 & 0.007390 & -0.241827 & 0.8118 \\
FGLOB & -0.060322 & 0.119170 & -0.506189 & 0.6192 \\
R & 0.000550 & 0.001010 & 0.544619 & 0.5931 \\
M & $-3.83 E-10$ & $1.18 E-08$ & -0.032430 & 0.9745 \\
FBY & 0.016076 & 0.046375 & 0.346664 & 0.7331 \\
INFL & $-4.03 E-05$ & 0.000631 & -0.063836 & 0.9498 \\
DPS & 0.031947 & 0.093016 & 0.343461 & 0.7355 \\
\hline \hline R-squared & 0.283913 & Mean dependent var & 0.052800 \\
Adjusted R-squared & -0.010946 & S.D. dependent var & 0.049288 \\
S.E. of regression & 0.049557 & Akaike info criterion & -2.917037 \\
Sum squared resid & 0.041751 & Schwarz criterion & -2.526997 \\
Log likelihood & 44.46297 & Hannan-Quinn criter. & -2.808857 \\
F-statistic & 0.962878 & Durbin-Watson stat & 1.918008 \\
Prob(F-statistic) & 0.487552 & & & \\
\hline \hline
\end{tabular}

Source: Authors' Computation

Table 4.2 above shows that the coefficient of determination (R2) of this Model II is 0.2839 which implies that a weak included explanatory variables.Hence, the model shows a weak goodness of fit in the short - run. This implies that only 28.4 percent of the included explanatory variables explained the growth rate of GDP in Nigeria, while other factors not included, known as stochastic of about 71.6 percent accounted for dependent variable changes in the short - run. Therefore, it is concluded economic globalization does not leads to growth rate of GDP, i.e economic growth, except other proactive actions were implemented in Nigeria between 1986 and 2010.

On a priori ground, only exchange rate(R), ratio of fiscal balance to GDP (FBY) and degree of Political stability (DPS) have an insignificant expected positive signs while others like trade globalization, financial globalization, money supply and inflation rate, all had a negative signs. This result confirms with previous studies that the relationship between economic globalization and economic growth are inverse in the developing countries, i.e the poor countries, get poorer in term of insignificant economic growth, while the advanced countries, get richer, in the context of economic globalization, as advocated by the anti-globalist and 
supported by the Dependency Growth theory, that is there is more of divergence in terms of economic growth than convergence among Less Developed Countries. However, the constant value of 0.041 in the model revealed that without economic globalization, the economic growth of Nigeria would be insignificant. Therefore, it becomes imperative for every country to embrace economic globalization philosophy/ ideology because no nation is an inland.

Finally, the Durbin - Watson value of 1.918 shows presence of positive autocorrelation and the $\mathrm{F}$ - statistics value of 0.9628 is statistically insignificant at $\mathrm{P}<0.05$. Therefore, it is concluded in this model that economic globalization do not leads to economic growth in Nigeria between 1986 and 2010. This empirical finding was supported with Awe, A. A. (2013) which examines the Impact of FDI on economic growth in Nigeria between 1976 and 2006 using a Two-Stage Least Squares method and found that there exist a negative relationship between economic growth (GDP) and foreign direct investment (FDI).

\section{Conclusion AND ReCOMmendation}

The empirical results of this study from the stand point of both Model I and II revealed that without economic globalization, there would be income inequality within Nigeria but a very insignificant economic growth would be recorded in the Nigeria economy. Hence, no nation is an island, which implies that every nation must embrace economic globalization and tap thegains of economic globalization depending on each nation's economic structure.Furthermore, it was established that there was a strong relationship between economic globalization and income inequality in Nigeria. Therefore, it was concluded empirically that economic globalization causes widening income inequality and reduces economic growth in the Nigerian economy due to much emphasis on financial globalization rather than trade globalization as well as macroeconomic imbalances such as poor governance, political instability, inadequate infrastructural facilities and others but to mention few between 1986 and 2010.

Based on the conclusion above, the following recommendations were made to optimize the gains of economic globalization and guaranteed higher economic growth and income equality within the country as follows:

- Government should encourage a massive Export promotions drive to exploit the gains of trade globalization across African and the World nations, just like China and Japan had dominated all larger markets of the World.

- Government should encouragedomestic Agricultural Exports among the teeming population of Nigerian citizens, which guarantees lager employment opportunities and reduces or eliminate income inequality as well as achieve a sustained economic growth and development respectively. This is established in the works of Florence et al (2008).

- Also as advocated by Kuznets (1955), the Government should demonstrate good governance at all tiers of government levels, in terms of protectionist domestic policy, fiscal efficiency, a relative political stability and a sound qualitative education to benefit immensely from the wave of economic globalization in the Nigeria economy.

- Finally, Government should provide adequate infrastructural facilities, in terms, power stability, good road networks, efficienttelecommunication system and others to benefit immensely from the presence of Foreign Direct Investment (Financial globalization in the country) as supported in the empirical findings as the causes of rising Income Inequality in the Nigerian Economy. 


\section{REFERENCES}

Abid Hameed and AnilaNazir (2005). Economic Globalization and its Impact on Poverty and Inequality: Evidence From Pakistan, Unpublished Paper.

Adams, S. (2007). "Globalization and Income Inequality: Implications for Intellectual Property Rights," Journal of Policy Modelling, Vol. 30, pp. 725-735.

Agion P. and J.G. Williamson (1998).Growth, inequality and globalization: theory, history and policy, Cambridge University Press.

Almas, Heshmati (2003). The relationship between Income Inequality and Globalization, The United Nations University, UNU/WIDER Paper, pp 1-31.

Anand, S. and S. Kanbur (1993). "Inequality and Development: A Critique." Journal of Development Economics 1:19 - 43.

Atif, Syed M., Srivastav Mudit, Sauytbekova Moldir, Arachchige, Udeni K. (2012). "Globalization and Income Inequality: A Panel Data Analysis of 68 Countries, Econstor Publications.

Awe, A.A. (2013). "The Impact of Foreign Direct Investment on Economic Growth in Nigeria, Journal of Economics and Sustainable Development, Vol. 4, No. 2, pp. 122-132.

Barro, R.J (2000). "Inequality and Growth in a Panel of countries. "Journal of Economic Growth 5:5-32.

Bergh, A. and Nilsson, T. (2011). "Do Liberalization and Globalization increase Income Inequality?",European Journal of Political Economy, VoI.26, pp. 683-722.

Bhagwati, J. (2004). “In Defense of Globalization “, New York: Oxford University Press, pp. 3.

Bhalla, S. (2002).Imagine There's no Country: Poverty, Inequality, and Growth in the Era of Globalization Washington, DC: Institute for international Economics.

Borsu, A. and H. Glejser (1992). "Do Protection, Schooling, Product Per Head and Income Distribution Influence Growth?" European Economic Review 36: 1235 - 39.

Chan, S. (1989). "Income Inequality among LDCs: A Comparative Analysis of Alternative Perspectives." International Studies Quarterly 33:45 - 66.

Cornia, G. (2003). "The Impact of Liberalization and Globalization on Income Inequality in Developing and Transitional Economics,"CESIfo Working Paper, No. 843. Pp. 1-32.

Cuadros, A., V. Orts and M. Alguacil (2004). “Openness and Growth: Re-Examining Foreign Direct Investment, Trade and Output Linkages in Latin America", Journal of Development Studies, Vol. 40 (1), pp. 53-68.

Edwards, S. (1997)."Trade Policy, Growth, and Income Distribution ", The American Economic Review, Vol. 87, No. 2, pp. 205-10.

Feenstra, R.C, and Hanson, G., (1997). Foreign Direct Investment and Relative Wages: Evidence from Mexico's Maquiladros", Journal of International Economics, Vol. 42, pp. 371-393.

Figini, P. and H. Gorg (1999). "Multinational Companies and wage Inequality in the Host Country: the Case of Ireland, "Trinity Economic Paper Series, Technical Paper, No. 98/16.

Florence J., Subir L., and Chris P. (2008). Rising Income Inequality: Technology, or Trade and Financial Globalization? IMF Working paper, Vol. 8, No. 185, pp 1-24.

Greenway, D., W. Morgan and P. Wright (2002). "Trade Liberalization and Growth in Developing Countries", Journal of Development Economics, Vol. 67, pp. 229-224.

Higgins, M., and J.G. Williamson (1999). "Explaining Inequality the World Round: Cohort Size, Kuznets Curves, and Openness." NBER Working Paper 7224.National Bureau of Economic Research, July.

Kemal, A.R., M. Din and U. Qadir (2002). "Global Research Project: Pakistan 'Country Report", Pakistan Institute of Development Economics, Islamabad.

Kuznets, S. (1955). "Economic Growth and Income Inequality." American Economic Review 45:3$6,17-26$. 
Lindert P.H. and J.G. Williamson (2001).Does globalization make the world more unequal?, University of California, Davis and Harvard University.

Loto, M.A. (2011). Globalization and Economic Development: The Nigerian Experience and Prospects (1980-2008), Journal of Emerging Trends in Economics and Management Sciences, Vol. 2, No. 3, pp. 160-167.

Mahler V.A. (2001).Economic Globalization, Domestic Politics and Income Inequality in the Developed Countries: A Cross-National Analysis, Luxembourg Income Study Working Paper No. 273.

Marjit, S., Beladi, H. and Chakrabarti, A. (2004). "Trade and Wage Inequality in Developing Countries", Economic Inquiry, Vol. 42, No. 2, pp. 295-303.

Milanovic, B. (2003). Can We Discern the Effect of Globalization and Income Distribution? Evidence from Household Budget Surveys, Policy Research Working Paper, No. 2876.

Muller, E.N. (1988). "Democracy, Economic Development, and Income Inequality." American sociological, Review 53:50 - 68.

Neutel, M. and A. Heshmati (2006).Globalization, Inequality and Poverty Relationships: A Cross Country Evidence, IAZ Discussion Paper, No. 2223.

O'Rouke K.H. (2001). Globalization and inequality: Historical trends, NBER 2001:8339.

OCED (2005). “OCED Handbook on Economic Globalization Indicators', pp. 11, viewed $3^{\text {rd }}$ October, 2012, http://www.realinstitutoelcano.org/materials/docs/OCDE Handbook. Pdf.

Reuveny, R. and Q. Li (2003). “Economic Openness, Democracy, and Income Inequality: An Empirical Analysis." Comparative Political Studies 36:575 - 601.

Round J. and J. Whalley (2002). "Globalization and Poverty: Implications of South Asian Experience for Wider Debate", DFID (Department of International Development) Project Paper.

Sato, S. and M. Fukushige (2009). "Globalization and Economic Inequality in the Short and Long Run: The Case of South Korea 1975-1995," Journal of Asian Economics, No. 20, pp. 62-68.

SeyedKomail T. and SepidehOhadi (2008). Relationship between Globalization and Inequality in different economic Blocks, Unpublished Work.

Wan, G.L.M. and Z. Chen (2007). "Globalization and Regional Income Inequality: Empirical Evidence from Within China," Review of Income and Health, series 53, No. 1.

Weede, E. and H. Tiefenbach (1981). "Some Recent Explanations of Income Inequality." International Studies Quarterly 23:255-82.

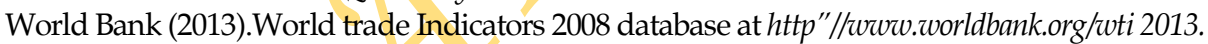

Zhou, L., Biswas, B., Bowles, T. and Saunders, PJ. (2011). "Impact of Globalization on Income Distribution Inequality in 60 Countries", Global Economy Journal, Vol. 11, No. 1, pp. 1-18. 